\title{
KARAKTERISASI MORFOLOGI SENGON (Paraserianthes falcataria L. Nielsen) HASIL MUTASI RADIASI SINAR GAMMA
}

\author{
Morphological Characterization of Sengon (Paraserianthes falcataria L. Nielsen) \\ Gamma Radiation Mutation Results
}

\author{
Roisatuz Zakiyah $^{1}$, Ulfah Juniarti Siregar ${ }^{2}$, dan N. Sri Hartati ${ }^{3}$ \\ ${ }^{1}$ Mahasiswa Pascasarjana Institut Pertanian Bogor \\ ${ }^{2}$ Staf Pengajar Departemen Silvikultur Fakultas Kehutanan IPB \\ ${ }^{3}$ Pusat Penelitian LIPI Cibinong
}

\begin{abstract}
Mutation is a process of change in genetic structure of particular organisme. Genetic changes due to mutation can produce new characteristic and increase genetic diversity, which will be utilized for improvement program. Several artificial mutation programs have proved to produce new superior individual. One common artificial mutation used is gamma radiation. This study aimed to characterize 9 years old gamma irradiated sengon trees, with doses 0 , 5, 10, and 15 krad based on its morphological characters, wood density, resistant to diseases. The observed parameters were tree diameter, height, volume, clear bole height, stem straightness, permanent branch, number of branches, canopy length, wood density and resistance to gall rust disease. Average values of all parameters of mutant lines does not differ significantly from control trees, however some individuals have better morphological characters than others. Mutant lines with 5 krad dose have close association with permanent branch and stem straightness, $15 \mathrm{krad}$ dose with volume, diameter, height and crown length, while $10 \mathrm{krad}$ with number of branches. Average wood density of mutant lines did not differ significantly from control either, with highest value belonged to $10 \mathrm{krad}$ dose. Selected superior tree candidates were individuals with number 5.07, K1, 15.27, and $15 \mathrm{NN}$.
\end{abstract}

Key word: breeding, characterization, mutation, sengon.

\section{PENDAHULUAN}

Kebutuhan kayu di Indonesia saat ini semakin meningkat. Berdasarkan data BPS (2015) produksi kayu untuk memenuhi bahan baku industri meningkat sebesar 50437 juta $\mathrm{m}^{3}$ pada tahun 2013 dibandingkan tahun 2012 sebesar 49258 juta m3 dan 47429 juta $\mathrm{m}^{3}$ pada tahun 2011. Sumbangan terbesar produksi kayu diberikan oleh hutan tanaman sebesar 29.67 juta $\mathrm{m}^{3}$. Sengon (Paraserianthes falcataria L. Nielsen) termasuk kedalam famili Fabaceae dan merupakan tanaman asli Indonesia yang tersebar di pulau Jawa, Sumatera, Kalimantan, Sulawesi, dan Irian Jaya (Santoso 1992). Sengon merupakan salah satu komoditas hutan tanaman yang memiliki kelebihan yaitu mudah dibudidaya, mudah tumbuh, dan memiliki nilai komersial.

Mutasi adalah proses perubahan struktur genetik yang terjadi pada suatu organisme. Gen yang berubah akibat adanya mutasi disebut mutan (Crowder 2006). Hasil mutasi akan menimbulkan gen baru dan meningkatkan keragaman genetik yang dapat digunakan untuk pemuliaan tanaman. Salah satu mutasi buatan yang umum digunakan adalah dengan radiasi sinar gamma untuk perbaikan mutu benih dan bibit serta untuk meningkatkan keragaman genetik guna memperoleh jenis unggul. Induksi mutasi dapat memperluas keragaman genetik dan dapat dilakukan dalam waktu yang relatif lebih singkat (Kendarini 2006).
Induksi mutasi terbagi menjadi dua yaitu mutagen fisika dan mutagen kimia. Mutagen fisika yaitu sinar gamma, sinar X, dan sinar UV. Mutagen kimia seperti etil metan sulfat (EMS), etil etan sulfanoat (EES), dan asam nitrit.

Radiasi sinar gamma adalah sinar yang dipancarkan dari isotop radioaktif yang memiliki daya tembus lebih kuat dibandingkan sinar X. Efek radiasi sinar gamma dapat menyebabkan perubahan genetik di dalam sel somatik dan menyebabkan terjadinya perubahan fenotip. Hutami et al. (2006) menyatakan bahwa keragaman somaklonal tanaman disebabkan karena adanya sel-sel yang bermutasi. Mutasi dapat terjadi pada setiap tahap perkembangan organisme. Crowder (2006) menyatakan bahwa dosis radiasi berbanding lurus dengan frekuensi mutasi. Pada beberapa penelitian diketahui bahwa dosis radiasi yang rendah mampu meningkatkan mutu bibit dan benih serta memperbaiki pertumbuhan tanaman. Sebaliknya, dosis yang tinggi dapat menyebabkan kematian (lethal) pada tanaman.

Hasil penelitian Zanzibar (2008) menunjukkan bahwa dosis radiasi sinar gamma sebesar 5 Gy yang diberikan pada benih suren (Toona sureni) mampu meningkatkan volume batang bibit suren umur 6 bulan sebesar $600 \%$ dibandingkan dengan kontrol, peningkatan tinggi sebesar $300 \%$ dan diameter sebesar $200 \%$. Pemuliaan mutasi sangat potensial dilakukan pada jenis-jenis tanaman kehutanan untuk meningkatkan keragaman pada jenis-jenis yang 
memiliki keragaman sempit atau untuk mendapatkan tanaman yang memiliki adaptasi terhadap kondisi lingkungan dan meningkatkan produktivitas.

Dosis radiasi yang diberikan pada penelitian ini yaitu $0,5,10$, dan $15 \mathrm{krad}$. Pengamatan terhadap bentuk morfologi dilakukan pada sengon mutan berumur 9 tahun. Tujuan dari penelitian ini adalah untuk mengkarakterisasi morfologi sengon hasil mutasi radiasi sinar gamma dan menganalisis kerapatan kayunya.

\section{METODE PENELITIAN}

\section{Waktu dan Lokasi Penelitian}

Penelitian ini dilaksanakan pada bulan FebruariApril 2016. Pengamatan bentuk morfologi pohon sengon di Kebun Plasma Nutfah-Pusat Penelitian Bioteknologi LIPI-Cibinong.

\section{Alat dan Bahan}

Alat yang digunakan dalam penelitian adalah haga hypsometer, tally sheet, pita ukur, kamera, bor riap, aluminium foil, timbangan analitik. Bahan yang digunakan yaitu tegakan sengon berumur 9 tahun.

\section{Prosedur Penelitian}

Penelitian ini merupakan penelitian lanjutan dari penelitian sebelumnya yang telah dilakukan oleh tim peneliti LIPI-Cibinong Bogor. Sudarmonowati et al. (2009) menginformasikan bahwa benih sengon yang diradiasi berasal dari Perhutani KPH Kediri. Dosis radiasi yang diberikan yaitu $0,5,10$, dan $15 \mathrm{krad}$. Benih sengon hasil radiasi ditanam di dalam polibag dengan media tanah bekas tambang dan kompos. Pemeliharaan tanaman dilakukan selama 3 bulan di dalam rumah kaca yang berada di Pusat-Penelitian Bioteknologi-LIPI Cibinong, Jawa Barat. Bibit yang mampu tumbuh setelah 3 bulan di dalam rumah kaca dipindahkan ke lapangan (Kebun Percobaan Pusat Penelitian Bioteknologi-LIPI Cibinong, Jawa Barat). Penanaman di lapangan dilakukan pada jarak tanam $3 \mathrm{~m}$ x $3 \mathrm{~m}$. Saat ini sengon hasil radiasi sudah berumur 9 tahun, maka dilakukan pengamatan kembali untuk melihat karakter morfologi dan pertumbuhannya.

\section{Penilaian Variabel Morfologi Pohon}

Variabel morfologi yang diamati adalah:

Diameter batang: Pengukuran dilakukan pada DBH (Diameter Breast Heigh).

Tinggi Pohon: Pengukuran tinggi pohon dilakukan dari pangkal batang sampai ujung titik tumbuh.

Volume pohon: Perhitungan volume didasarkan pada nilai tinggi dan diameter pohon. Angka bentuk yang digunakan untuk menduga volume sebesar 0.74 (Susila 2011)

Tinggi Bebas Cabang: Pengukuran dilakukan mulai dari pangkal sampai posisi cabang pertama yang memiliki ukuran $>30 \%$ dibandingkan diameter batang tempat kedudukannya ICWRMIP-CWMBC (2013).
Kelurusan batang: Pengukuran dimulai dari pangkal batang hingga ditemukan tanda-tanda kebengkokan atau batang lebih dari satu (multy steam).

Cabang permanen: Cabang permanen memiliki ukuran diameternya $>30 \%$ diameter batang tempat kedudukannya. Pengukuran dilakukan dari mulai pangkal hingga kedudukan cabang permanen ICWRMIP-CWMBC (2013).

Tajuk: pengukuran tajuk dilakukan dengan mengukur tajuk terpanjang dan terpendek (Wijayanto dan Nurunnajah 2012)

Jumlah Cabang: pengukuran jumlah cabang dilakukan dengan menghitung seluruh cabang yang terdapat dalam setiap pohon.

\section{Seleksi Pohon Plus}

Pemilihan pohon plus dalam penelitian ini dilakukan berdasarkan ICWRMIP-CWMBC (2013). Kandidat pohon plus ditentukan dengan memilih pohon fenotip terbaik dan letak pohon tidak berada paling luar (pinggir batas). Metode penilaian dilakukan dengan sistem pohon pembanding, yaitu untuk setiap kandidat pohon plus terpilih dibandingkan dengan 5 pohon terdekat.

\section{Analisis Kerapatan Kayu}

Nilai kerapatan kayu dapat ditentukan dengan persamaan sebagai berikut (Suhaya dan Erningtyas 2005):

$$
\rho=\frac{B K U}{V K U}
$$

\section{Keterangan:}

$\rho \quad=$ Kerapatan kayu $\left(\mathrm{g} \mathrm{cm}^{-3}\right)$

$\mathrm{BKU}=$ Berat contoh uji kondisi kering udara $(\mathrm{g})$

$\mathrm{VKU}=$ Volume contoh uji kondisi kering udara $\left(\mathrm{cm}^{-3}\right)$

\section{Perhitungan Intensitas dan Luas Serangan Penyakit}

Intensitas serangan yang terjadi dihitung menggunakan rumus menurut Laksono et al. (2010):

$$
I S=\frac{\sum(n i \times V i)}{N \times V} \times 100 \%
$$

Keterangan:

IS = Intesitas serangan $(\%)$

ni = Banyak tanaman yang diamati dengan skor ke-i

vi $=$ Skor tanaman ke-i

$\mathrm{N}=$ Total tanaman yang diamati

$\mathrm{V}=$ Skor serangan tertinggi

\section{Analisis Data Morfologi}

Data morfologi yang diperoleh dari hasil pengukuran di lapangan dianalisis dengan uji nonparametrik Kruskall-Wallis dengan uji lanjut Dunn untuk melihat perlakuan mana yang memberikan pengaruh nyata, analisis multi variant yang terdiri dari Principal Component Analysis (PCA) dan BIPLOT, serta analisis distribusi frekuensi. Data diolah dengan menggunakan software Minitab. 


\section{HASIL DAN PEMBAHASAN}

Analisis uji non-parametrik Kruskall-Wallis merupakan metode analisis data yang tidak mementingkan rancangan dalam percobaan. Hasil uji Kruskall-Wallis menunjukkan bahwa dosis radiasi yang diberikan pada tanaman sengon tidak memberikan pengaruh yang nyata karena nilai sig semua parameter lebih besar dari 0.10. Hasil uji Dunn (Tabel 1) menunjukkan nilai rata-rata tiap parameter pada berbagai dosis radiasi tidak berbeda signifikan dengan kontrol.

Dosis $15 \mathrm{krad}$ memiliki nila rata-rata tertinggi untuk tinggi, diameter dan volume (Tabel 1). Hasil Tabel 1 menunjukkan pada setiap variabel terjadi peningkatan nilai rata-rata dari nilai tanaman kontrol ke perlakuan dosis $5 \mathrm{krad}$, kemudian menurun pada dosis $10 \mathrm{krad}$ dan meningkat kembali pada dosis 15 krad. Menurut Bhikuningputro (1976) perubahan-perubahan morfologi, fisiologi, dan genetik mulai dan baru terjadi pada dosis penyinaran $20 \mathrm{krad}$ dan pada dosis $40-50 \mathrm{krad}$ epikotil dan daun tanaman tidak tumbuh dan kemudian mati. Radiasi benih menggunakan dosis yang tinggi mengganggu sintesis protein, keseimbangan hormon, pertukaran gas, pertukaran air dan aktifitas enzim yang memicu gangguan terhadap morfologi dan fisiologi tanaman serta dapat menghambat pertumbuhan dan perkembangan tanaman (Hameed et al. 2008).

Dosis $5 \mathrm{krad}$ memiliki nilai rata-rata paling tinggi untuk TBC dan $\mathrm{CP}$, sedangkan untuk kelurusan batang (KB) nilai rata-rata tertinggi yaitu pada kontrol (Tabel
2). Secara keseluruhan hasil penelitian ini menunjukkan bahwa pada saat ditanam di lapangan, pertumbuhan bibit sengon hasil radiasi secara umum tidak berbeda jauh dengan kontrol. Kondisi lingkungan kemungkinan menjadi faktor tidak adanya perbedaan pertumbuhan antara tanaman sengon yang diberikan perlakuan radiasi dengan kontrol yang ditanam di lapangan. Penelitian sebelumnya oleh Sudarmonowati et al. (2009) pada tanaman yang sama telah dilakukan seleksi individu yang tahan terhadap tanah tambang menggunakan media tanah bekas tambang dan media campuran kompos, sedangkan saat ini sengon hasil radiasi tersebut tidak ditanam pada tanah bekas tambang melainkan di tanah biasa yang kesuburannya lebih baik.

Besarnya nilai pertumbuhan suatu tanaman ditentukan oleh adanya interaksi antara faktor genetik dengan faktor lingkungan tempat tumbuhan tersebut tumbuh (Marjenah 2003). Karakter morfologi seperti tinggi, diameter, dan batang bebas cabang merupakan karakteristik yang dikendalikan oleh gen dan sangat dipengaruhi oleh lingkungan (Hardiyanto et al. 2007). Interaksi genetik dan lingkungan berhubungan dengan kemampuan adaptasi yang dimiliki oleh suatu individu atau populasi tanaman pada lingkungan tertentu. Faktor genetik merupakan salah satu faktor yang sangat menentukan sifat dari tanaman. Faktor lingkungan juga sangat berperan dalam proses pertumbuhan tanaman. Kondisi lingkungan yang sesuai dengan jenis tanaman akan menghasilkan pertumbuhan yang baik (Hayati et al. 2012).

Tabel 1 Rata-rata tinggi, diameter, dan volume sengon mutan hasil radiasi sinar gamma

\begin{tabular}{clcc}
\hline \multirow{2}{*}{ Dosis $(\mathrm{krad})$} & \multicolumn{3}{c}{ Nilai rata-rata beberapa variabel sengon mutan hasil radiasi sinar gamma yang diuji } \\
\cline { 2 - 4 } & Tinggi $(\mathrm{m})$ & Diameter $(\mathrm{cm})$ & Volume $\left(\mathrm{m}^{3}\right)$ \\
\hline 0 & $28.33 \pm 2.0866 \mathrm{a}$ & $27.36 \pm 3.3914 \mathrm{a}$ & $1.56 \pm 0.4589 \mathrm{a}$ \\
5 & $28.65 \pm 1.1788 \mathrm{a}$ & $29.20 \pm 2.2757 \mathrm{a}$ & $1.64 \pm 0.2639 \mathrm{a}$ \\
10 & $26.28 \pm 3.3521 \mathrm{a}$ & $23.04 \pm 4.3976 \mathrm{a}$ & $1.19 \pm 0.5745 \mathrm{a}$ \\
15 & $29.84 \pm 1.3266 \mathrm{a}$ & $33.49 \pm 2.6587 \mathrm{a}$ & $2.16 \pm 0.3468 \mathrm{a}$ \\
\hline
\end{tabular}

Huruf yang sama pada kolom yang sama menunjukkan perlakuan tidak berpengaruh nyata terhadap parameter yang diuji.

Tabel 2 Rata-rata TBC, KB, dan CP sengon mutan hasil radiasi sinar gamma

\begin{tabular}{|c|c|c|c|}
\hline \multirow[t]{2}{*}{ Dosis (krad) } & \multicolumn{3}{|c|}{ Nilai rata-rata beberapa variabel sengon mutan hasil radiasi sinar gamma yang diuji } \\
\hline & TBC (m) & $\mathrm{KB}(\mathrm{m})$ & $\mathrm{CP}(\mathrm{m})$ \\
\hline 0 & $14.56 \pm 2.5103 \mathrm{a}$ & $10.67 \pm 2.7538 \mathrm{a}$ & $14.83 \pm 2.2142 \mathrm{a}$ \\
\hline 5 & $14.62 \pm 1.9655 \mathrm{a}$ & $9.02 \pm 1.3134 \mathrm{a}$ & $16.27 \pm 1.8459 \mathrm{a}$ \\
\hline 10 & $12.93 \pm 2.5644 \mathrm{a}$ & $6.93 \pm 1.4977 \mathrm{a}$ & $14.14 \pm 2.2192 \mathrm{a}$ \\
\hline 15 & $12.31 \pm 1.5605 \mathrm{a}$ & $6.97 \pm 1.2794 \mathrm{a}$ & $14.06 \pm 1.6850 \mathrm{a}$ \\
\hline
\end{tabular}

TBC: Tinggi bebas cabang; KB: Kelurusan batang; CP: Cabang permanen

Huruf yang sama pada kolom yang sama menunjukkan perlakuan tidak berpengaruh nyata terhadap parameter yang diuji.

Tabel 3 Rata-rata jumlah cabang dan panjang tajuk sengon mutan hasil radiasi sinar gamma

\begin{tabular}{ccc}
\hline \multirow{2}{*}{ Dosis $(\mathrm{krad})$} & \multicolumn{2}{c}{ Nilai rata-rata jumlah cabang dan panjang tajuk } \\
\cline { 2 - 3 } & Jumlah cabang & Panjang Tajuk $(\mathrm{m})$ \\
\hline 0 & $6.00 \pm 0.9969 \mathrm{a}$ & $2.47 \pm 0.4648 \mathrm{a}$ \\
5 & $6.00 \pm 0.7763 \mathrm{a}$ & $2.66 \pm 0.2157 \mathrm{a}$ \\
10 & $7.00 \pm 1.2724 \mathrm{a}$ & $2.36 \pm 0.4422 \mathrm{a}$ \\
15 & $7.00 \pm 0.7890 \mathrm{a}$ & $3.34 \pm 0.3148 \mathrm{a}$ \\
\hline
\end{tabular}

Huruf yang sama pada kolom yang sama menunjukkan perlakuan tidak berpengaruh nyata terhadap parameter yang diuji. 


\section{Tajuk dan Jumlah Cabang}

Hasil uji Dunn pada variabel jumlah cabang dan panjang tajuk (Tabel 3) tidak menunjukkan perbedaan yang nyata pada setiap dosis radiasi yang diberikan. Jumlah cabang pohon berbanding lurus dengan dosis radiasi yang diberikan. Dosis yang lebih tinggi menghasilkan jumlah cabang yang lebih banyak dibandingkan dosis yang rendah (Tabel 3). Dosis 15 krad memiliki jumlah cabang terbanyak dan nilai ratarata tajuk tertinggi dibandingkan dosis lainnya.

Perlakuan radiasi yang diberikan pada tanaman kemungkinan dapat merubah sifat percabangan. Hasil penelitian Dewi dan Dwimahyani (2013) tentang radiasi sinar gamma yang diberikan pada tanaman kembang sepatu (Hibiscus rosa-sinensis) menunjukkan bahwa pada dosis radiasi 10-20 Gy menimbulkan pertumbuhan tanaman yang kerdil dan terjadi penurunan jumlah cabang. Dosis $15 \mathrm{krad}$ memiliki nilai rata-rata tajuk tertinggi dibandingkan dosis lainnya (Tabel 3). Hasil penelitian Purwati dan Hariyono (2010) juga menunjukkan dosis radiasi yang tinggi (200 Gy) menyebabkan pertambahan lebar kanopi tanaman jarak pagar dibandingkan pada dosis yang lebih rendah (100$150 \mathrm{~Gy})$.

\section{Analisis PCA (Principal Component Analysis)}

Analisis PCA bertujuan untuk mengetahui hubungan antara variabel yang digunakan dalam penelitian secara bersamaan (Supranto 2004).

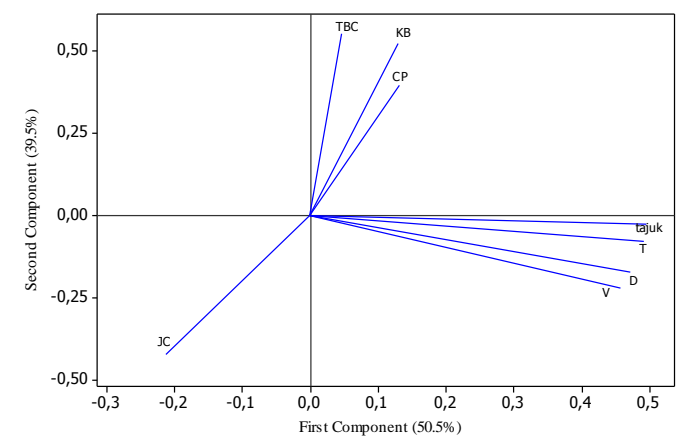

Gambar 1 Hasil analisis PCA pada delapan variabel yang diamati dalam penelitian sengon hasil radiasi sinar gamma

Keterangan: TBC (tinggi bebas cabang); KB (kelurusan batang); CP (cabang permanen); T (tinggi); D (diameter); V (volume); JC (jumlah cabang).

Hubungan diantara variabel dapat dilihat dari sudut yang terbentuk diantara variabel, semakin kecil sudut yang terbentuk maka semakin kuat hubungan diantara variabel. Variabel yang memiliki hubungan kuat artinya karakter tersebut memiliki kesamaan pada setiap jenis sengon pada berbagai dosis radiasi sinar gamma. Hal ini dapat diartikan bahwa variabel yang memiliki hubungan kuat tersebut dapat dipilih salah satu saja untuk melihat perbedaan dari pengaruh dosis radiasi sinar gamma terhadap pertumbuhan sengon.

\section{Analisis BIPLOT}

Analisis BIPLOT digunakan untuk mengetahui variabel apa yang paling mencirikan pada tiap dosis radiasi yang digunakan dalam penelitian ini. Karakteristik sengon hasil radiasi sinar gamma dapat dicirikan dari posisi terdekat titik dengan variabel yang diamati.

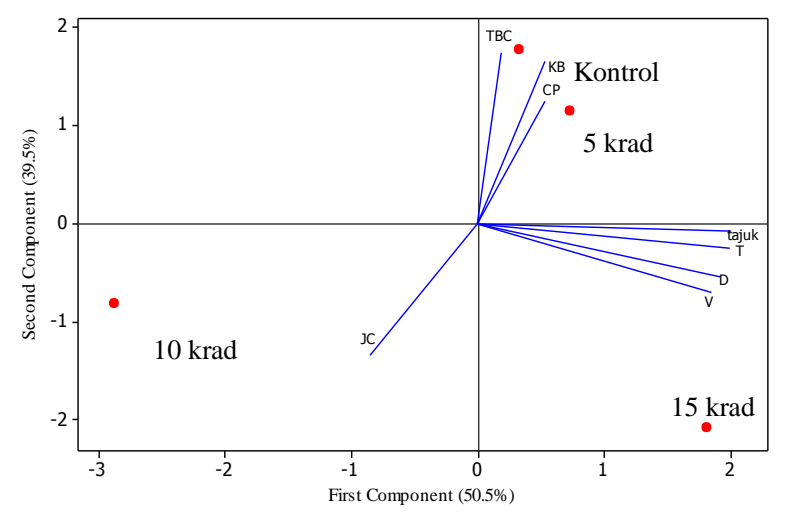

Gambar 2 Hasil analisis BIPLOT pada delapan variabel yang diamati dalam penelitian sengon hasil radiasi sinar gamma

Keterangan: TBC (tinggi bebas cabang); KB (kelurusan batang); CP (cabang permanen); T (tinggi); D (diameter); V (volume); JC (jumlah cabang).

Gambar 2 menunjukkan kontrol memiliki ciri karakteristik TBC dan KB yang tinggi. Dosis $5 \mathrm{krad}$ memiliki kedekatan dengan karakteristik $\mathrm{CP}$ dan $\mathrm{KB}$. Tanaman dosis radiasi $15 \mathrm{krad}$ cenderung memiliki ciri karakteristik V, D, T dan tajuk yang cenderung tinggi dan dosis radiasi $10 \mathrm{krad}$ cenderung memiliki karakteristik JC yang tinggi. Berdasarkan Gambar 5 diketahui sengon hasil radiasi dosis $10 \mathrm{krad}$ terletak berlawanan arah dengan semua variabel kecuali variabel jumlah cabang. Artinya sengon hasil radiasi dosis 10 krad memiliki nilai lebih rendah pada tujuh variabel tersebut.

\section{Seleksi Pohon Sengon Hasil Radiasi Berdasarkan Diameter dan Volume}

Penggunaan teknologi radiasi sinar gamma untuk pemuliaan tidak dapat diprediksi hasilnya karena mutasi yang dihasilkan dari radiasi sinar gamma bersifat acak. Individu yang diradiasi dengan dosis yang sama belum tentu memiliki karakter yang sama pula. Respon terhadap iradiasi masing-masing jenis benih berbeda, dipengaruhi oleh radiosensitivitas berupa kondisi fisikfisiologis, genetik, dan lingkungan (Zanzibar 2015). Selain itu keberhasilan program induksi mutasi juga sangat bergantung pada materi tanaman yang mendapat perlakuan mutagen. Berdasarkan data individu pohon dari nilai minimum dan maksimum tiap perlakuan pada delapan parameter terdapat individu yang memiliki nilai diameter dan volume lebih besar dari kontrol. Tabel nilai frekuensi sebaran diameter digunakan untuk mengetahui individu yang memiliki nilai diameter tertinggi pada dosis tertentu. Frekuensi nilai sebaran diameter (Tabel 4) menunjukkan sebaran diameter pada beberapa selang kelas.

Sengon pada umur 9 tahun menurut Subari (2014) memiliki diameter $40.5 \mathrm{~cm}$. Hasil Tabel 4 menunjukkan individu sengon hasil radiasi pada dosis 5 dan $15 \mathrm{krad}$ 
memiliki potensi untuk dibudidayakan dengan tujuan kayu pertukangan karena memiliki individu dengan diameter yang lebih besar dibandingkan diameter sengon pada umumnya.

Tabel 4 Frekuensi sebaran nilai diameter sengon mutan hasil radiasi sinar gamma

\begin{tabular}{ccccc}
\hline \multirow{2}{*}{$\begin{array}{c}\text { Selang kelas } \\
(\mathrm{cm})\end{array}$} & \multicolumn{4}{c}{ Persentase $(\%) /$ dosis radiasi } \\
\cline { 2 - 5 } & $0 \mathrm{krad}$ & $5 \mathrm{krad}$ & $10 \mathrm{krad}$ & $15 \mathrm{krad}$ \\
\hline $9-16$ & 11.11 & 5.0 & 28.57 & \\
$17-24$ & 33.33 & 35.0 & 42.86 & 31.25 \\
$25-32$ & 33.33 & 20.0 & 14.28 & 18.75 \\
$33-40$ & & 25.0 & & 31.25 \\
$41-48$ & 22.22 & 5.0 & 14.28 & 6.25 \\
$49-56$ & & 10.0 & & 12.5 \\
\hline
\end{tabular}

Tabel 5 Frekuensi sebaran nilai volume sengon mutan hasil radiasi sinar gamma.

\begin{tabular}{cllll}
\hline $\begin{array}{c}\text { Selang kelas } \\
\left(\mathrm{m}^{3}\right)\end{array}$ & \multicolumn{4}{c}{ Persentase $(\%)$} \\
\cline { 2 - 5 } & $0 \mathrm{krad}$ & $5 \mathrm{krad}$ & $10 \mathrm{krad}$ & $15 \mathrm{krad}$ \\
\hline $0.070-0.93$ & 44.44 & 40.0 & 57.14 & 25.0 \\
$0.985-1.845$ & 33.33 & 20.0 & 28.57 & 25.0 \\
$1.945-2.805$ & & 25.0 & & 18.75 \\
$2.905-3.765$ & 11.11 & 5.0 & & 18.75 \\
$3.865-4.725$ & 11.11 & 10.0 & 14.28 & 6.25 \\
$4.825-5.685$ & & & & 6.25 \\
\hline
\end{tabular}

Hasil dari Tabel 4 dan Tabel 5 menunjukkan individu yang memiliki nilai diameter dan volume terbesar yaitu kode 15149 hasil radiasi dosis $15 \mathrm{krad}$. Individu dengan kode 15149 telah memiliki adaptabilitas dan kemampuan tumbuh yang baik pada saat di rumah kaca. Nilai diameternya dari awal pengamatan hingga $4 \mathrm{mst}$ berturut-turut yaitu $0.15 \mathrm{~cm}$, $0.25 \mathrm{~cm}$, dan $0.40 \mathrm{~cm}$ [data tidak dipubllikasi].

\section{Identifikasi Penyakit Sengon Mutan Hasil Radiasi Sinar Gamma}

Hasil perhitungan terhadap intensitas dan luas serangan penyakit karat puru pada sengon mutan hasil radiasi sinar gamma terdapat pada Tabel 6.

Intesitas serangan (IS) dan luas serangan (LS) penyakit pada bagian cabang tanaman kontrol lebih rendah dibandingkan dengan tanaman yang diradiasi (Tabel 6). Pemberian radiasi diduga tidak mempengaruhi ketahanan terhadap karat puru pada sengon. Dosis radiasi 70-130 krad mampu menghilangkan serangga pada kayu, tetapi untuk menghilangkan fungi membutuhkan dosis yang lebih tinggi (Kunstadt 1998). Hal yang menyebabkan fungi lebih resisten terhadap iradiasi adalah karena fungi sering mengalami fase dorman dan beberapa fungi dapat bereproduksi secara aseksual sehingga dampak kemandulan yang ditimbulkan lebih kecil.

\section{Seleksi Pohon Plus}

Pemilihan pohon plus dipilih berdasarkan hasil pengamatan terhadap karakter morfologi. Individu yang dipilih sebagai kandidat pohon plus yang memiliki karakter lebih baik dibandingkan dengan lainnya. Hasil skoring beberapa kandidat pohon plus disajikan pada Tabel 7 .

Tabel 6 Intensitas dan luas serangan penyakit karat puru sengon mutan hasil radiasi sinar gamma

\begin{tabular}{lllllllll}
\hline \multirow{2}{*}{ Bagian pohon } & \multicolumn{7}{c}{ Dosis radiasi } \\
\cline { 2 - 9 } & \multicolumn{2}{c}{ Kontrol } & \multicolumn{2}{c}{$5 \mathrm{krad}$} & \multicolumn{2}{c}{$10 \mathrm{krad}$} & \multicolumn{1}{c}{$15 \mathrm{krad}$} \\
\hline & & IS (\%) & LS (\%) & IS (\%) & LS (\%) & IS (\%) & LS (\%) & IS (\%) \\
\cline { 2 - 10 } Ranting & 22.22 & 8.33 & 20.00 & 6.25 & - & - & 18.75 & 6.25 \\
Cabang & 22.22 & 8.33 & 45.00 & 11.25 & 42.86 & 14.28 & 31.25 & 9.37 \\
Batang & - & - & 5.00 & 1.25 & - & - & 6.25 & 3.12 \\
\hline
\end{tabular}

Keterangan: IS: Intesitas serangan; LS: Luas serangan

Tabel 7 Hasil skoring beberapa parameter pada kandidat pohon plus

\begin{tabular}{|c|c|c|c|c|c|c|c|c|c|c|c|}
\hline \multirow{2}{*}{$\begin{array}{c}\text { Kandidat } \\
\text { pohon } \\
\text { plus }\end{array}$} & \multirow{2}{*}{$\begin{array}{l}\text { Kode } \\
\text { lapang }\end{array}$} & \multicolumn{9}{|c|}{ Skor dari parameter yang diamati } & \multirow{2}{*}{$\begin{array}{l}\text { Total } \\
\text { Skor }\end{array}$} \\
\hline & & $\begin{array}{c}\mathrm{D} \\
(\mathrm{cm})\end{array}$ & D asli & $\begin{array}{c}\mathrm{T} \\
(\mathrm{m})\end{array}$ & $\begin{array}{c}\mathrm{T} \\
\text { asli }\end{array}$ & $\begin{array}{c}\text { TBC } \\
(\mathrm{m})\end{array}$ & $\begin{array}{l}\mathrm{KB} \\
(\mathrm{m})\end{array}$ & $\begin{array}{l}\mathrm{CP} \\
(\mathrm{m}) \\
\end{array}$ & $\begin{array}{c}\text { Cacat } \\
\text { lain }\end{array}$ & $\mathrm{BB}$ & \\
\hline 1 & K1 & 30 & 31.37 & 20 & 31 & 15 & 5 & 3 & 5 & 3 & $143.37^{*}$ \\
\hline 2 & 15.27 & 30 & 36.56 & 20 & 35.5 & 12 & 0 & 0 & 5 & 3 & $142.06^{*}$ \\
\hline 3 & 5.07 & 30 & 30.16 & 20 & 36 & 12 & 5 & 3 & 5 & 3 & $144.16 *$ \\
\hline 4 & 5.04 & 17 & 26.59 & 4 & 25 & 15 & 5 & 3 & 5 & 3 & 103.59 \\
\hline 5 & 5.24 & 30 & 39.01 & 18 & 30 & 3 & 0 & 0 & 5 & 3 & 128.01 \\
\hline 6 & 5.09 & 30 & 35.73 & 20 & 35 & 3 & 0 & 0 & 5 & 3 & $131.37 *$ \\
\hline 7 & $15 \mathrm{NN}$ & 30 & 31.78 & 18 & 34 & 9 & 0 & 0 & 5 & 3 & $130.78 *$ \\
\hline 8 & 15.61 & 17 & 26.43 & 18 & 34 & 12 & 0 & 7 & 5 & 3 & 122.43 \\
\hline 9 & K 2 & 30 & 30.50 & 12 & 31 & 3 & 3 & 3 & 5 & 3 & 120.5 \\
\hline 10 & 5.18 & 5 & 32.74 & 12 & 33.5 & 15 & 3 & 3 & 5 & 3 & 112.24 \\
\hline
\end{tabular}

Keterangan : D: Diameter, T: tinggi, TBC: tinggi bebas cabang, KB: kelurusan batang, $\mathrm{CP}$ : cabang permanen, $\mathrm{BB}$ : bentuk batang, A: ada, TA: tidak ada, AB: agak bulat *= kandidat pohon plus terpilih, K : Kontrol, 5.07 (dosis $5 \mathrm{krad}), 15.61$ (dosis $15 \mathrm{krad})$ 
Nilai skor 5 kandidat pohon plus (Tabel 7) berkisar antara 130.78-144.16. Nilai batas kelulusan yang terlalu tinggi akan menyebabkan jumlah pohon plus yang dipilih lebih sedikit dan akan menyempitkan variasi genetik, sebaliknya nilai batas skor yang terlalu rendah akan memberikan nilai genetik yang rendah. Kandidat pohon plus yang memiliki total skor tertinggi (Tabel 7) adalah kandidat nomor 3 dengan total skor sebesar 144.16, pohon tersebut merupakan pohon hasil radiasi 5 krad. Urutan ke-2, 3, 4, dan 5 dengan skor total masingmasing yaitu 143.37 (kontrol), 142.06 (15 krad), 131.37 (5 krad), dan 130.78 (15 krad). Pohon dengan diameter dan tinggi yang besar akan menghasilkan volume yang tinggi pula. Volume suatu pohon biasanya digunakan untuk menentukan harga jual pohon tersebut. Semakin besar volumenya, maka nilai jualnya akan semakin tinggi.

\section{Analisis Kerapatan Kayu}

Kerapatan kayu sengon tergolong kedalam kerapatan yang rendah yaitu $0.31 \mathrm{~g} / \mathrm{cm}^{3}$ (Nandika et al. 2014). Hasil penelitian (Tabel 8) menunjukkan bahwa nilai rata-rata kayu sengon hasil radiasi memiliki nilai kerapatan lebih besar dari nilai kerapatan rata-rata sengon pada umumnya walaupun nilai tersebut masih termasuk dalam kategori rendah yaitu kurang dari 0.6 $\mathrm{g} / \mathrm{cm}^{3}$ (Ardiansa et al. 2014). Kayu yang berkerapatan rendah umumnya tersusun atas diameter yang relatif besar dengan dinding sel tipis dan rongga sel yang besar.

Tabel 8 Hasil uji lanjut Dunn terhadap nilai kerapatan kayu sengon mutan hasil radiasi sinar gamma

\begin{tabular}{cl}
\hline Dosis $(\mathrm{krad})$ & Rata-rata $\left(\mathrm{g} / \mathrm{cm}^{3}\right)$ \\
\hline 0 & $0.4720 \pm 0.0459 \mathrm{a}$ \\
5 & $0.3880 \pm 0.0407 \mathrm{ab}$ \\
10 & $0.4840 \pm 0.0344 \mathrm{a}$ \\
15 & $0.3360 \pm 0.0346 \mathrm{~b}$ \\
\hline
\end{tabular}

Huruf yang sama pada kolom yang sama menunjukkan perlakuan tidak berpengaruh nyata terhadap parameter yang diuji.

Radiasi sinar gamma yang diberikan pada tanaman sengon dalam penelitian ini tidak memberikan pengaruh yang berbeda terhadap kerapatan kayunya. Sesuai dengan penelitian Severiano et al. (2010) yang menunjukkan bahwa radiasi sinar gamma pada dosis 25-100 KGy tidak memberikan pengaruh terhadap sifat fisik, kimia, dan kayu. Curling dan Winandy (2008) juga melaporkan bahwa radiasi yang diberikan pada kayu pinus tidak menyebabkan perubahan nilai kerapatan kayunya. Kerapatan merupakan sifat fisik kayu yang berpengaruh terhadap kekuatan dan keawetan kayu. Kayu yang memiliki kerapatan rendah akan memiliki kemampuan menahan beban yang lebih rendah serta lebih rentan terhadap hama dan penyakit yang menyerang kayu.

\section{SIMPULAN}

Individu kandidat pohon plus yaitu individu dengan nomor lapang 5.07, K1, 15.27, 5.09, dan 15.NN. Sengon kontrol memiliki ciri karakteristik TBC (tinggi bebas cabang) dan KB (kelurusan batang) yang tinggi. Sedangkan sengon hasil radiasi dosis 5 krad memiliki ciri karakteristik CP (cabang permanen) dan KB (kelurusan batang) yang tinggi. Dosis $15 \mathrm{krad}$ cenderung memiliki ciri karakteristik V (volume), D (diameter), $\mathrm{T}$ (tinggi) dan tajuk yang cenderung tinggi dan dosis $10 \mathrm{krad}$ cenderung memiliki karakteristik JC (jumlah cabang) yang tinggi. Nilai rata-rata kerapatan kayu antara tanaman hasil radiasi dengan kontrol tidak berbeda signifikan. Nilai rata-rata kerapatan kayu terbesar terdapat pada dosis $10 \mathrm{krad}$.

\section{SARAN}

Penelitian pemuliaan mutasi pada tanaman kehutanan masih sedikit dilakukan. Oleh karena itu perlu dilakukan penelitian-penelitian lain dengan menggunakan jenis tanaman kehutanan lainnya. Pengamatan morfologi terhadap tanaman hasil mutasi harus dilakukan secara berkala misal 6 bulan sekali untuk mengetahui proses perubahan yang terjadi pada setiap individu sehingga menghasilkan individu yang unggul dan memiliki karakter yang konsisten.

\section{DAFTAR PUSTAKA}

Ardiansa B, Ariyanti, Hapid A. 2014. Pengaruh konsentrasi dan lama perendaman kayu sengon (Paraserianthes falcataria L. Nielsen) dalam ekstrak daun sirsak (Annona muricata L.) terhadap serangan rayap tanah (Coptotermes sp.). Jurnal Warta Rimba 2(1): 81-87.

[BPS] Badan Pusat Statistik. Analisis Rumah Tangga Usaha Bidang Kehutanan dan Rumah Tangga Kehutanan. 2015. Jakarta (ID): Badan Pusat Statistik.

Bhikuningputro W. 1976. Pengaruh radiasi sinar gamma terhadap susunan anatomi tanaman kedelai (Glycine Max. Merr) [Laporan Hasil Penelitian]. Pusat Penelitian Atom Nasional. Yogyakarta (ID): Badan Tenaga Atom Nasional.

Crowder LV. 2006. Genetika Tumbuhan. Kusdiarti L, penerjemah; Soetarso, editor. Yogyakarta (ID): Gadjah Mada University Press. Terjemahan dari: Plant Genetik

Curling S, Winandy JE. 2008. Comparison of the effects of gamma irradiation and steam sterilization on southern pine sapwood. Forest Products Journal 58(1): 87-90.

Dewi AK, Dwimahyani I. 2013. Pengaruh radiasi gamma terhadap perubahan morfoogi pertumbuhan stek tanaman kembang sepatu (Hibiscus rosasinensis). Majalah Ilmiah Aplikasi Isotop da Radiasi BETA GAMMA 4(2): 89-101.

Hameed A, Shah TM, Atta MB, Haq MA, Sayed H. 2008. Gamma irradiation effects on seed germination and growth, protein content, peroxidase and protease activity, lipid peroxidation in desi and kabuli chickpea. Pakistan Journal of Botany 40: 1033-1041. 
Hardiyanto E, Mujiarto, S Sulasmi E. 2007. Kekerabatan genetik beberapa spesies jeruk berdasarkan taksonometri. Jurnal Hort. 17(3): 203 216.

Hayati E, Sabaruddin, Rahmawati. 2012. Pengaruh jumlah mata tunas dan komposisi media tanam terhadap pertumbuhan stek tanaman jarak pagar (Jatropha curcas L.). Jurnal Agrista 16(3): 129-134.

Hutami S, I Mariska, Y Supriati. 2005. Peningkatan keragaman genetik tanaman melalui keragaman somaklonal. Jurnal Agro Biogen. 2(2): 81-88.

[ICWRMIP-CWMBC] Integrated Citarum Water Resource management Investment Program-Citarum Watershed Management and Biodiversity Conservation. Modul Pelatihan Penunjukkan Pohon Plus: Urgensi, Sistem Penilaian dan Karakter Penting. 2013. Bandung (ID): Pilot Proyek Restorasi/Rehabilitasi Lahan (PPR/RL).

Kendarini N. 2006. Penggunaan radiasi sinar gamma untuk induksi keragaman somaklonal pada krisan (Dendranthema grandiflora Tzvelev) [tesis]. Bogor (ID): Institut Pertanian Bogor.

Kunstadt P. 1998. Radiation disinfestation of wood products. Radiat Phys Chem. 1(52): 617-623.

Laksono KD, Nasahi C, Susniahti N. 2010. Inventarisasi penyakit pada tanaman jarak pagar (Jatropha curcas L.) pada tiga daerah di Jawa Barat. Jurnal Agrikultura 21(1): 31-38.

Marjenah. 2004. Hubungan antar jarak tanam dengan tinggi dan diameter tanaman jati (Tectona grandis Linn.f) di Kalimantan Timur. Jurnal RIMBA Kalimantan Fakultas Kehutanan Unmul 11(1): 2126.

Nandika D, Darmawan W, Arinana. 2014. Peningkatan kualitas kayu sengon (Paraserianthes falcataria L. Nielsen) melalui teknik kompregnasi. Jurnal Teknologi Industri Pertanian 25(2): 125-135.

Purwati RD, Hariyono B. 2010. Aplikasi teknologi radiasi dalam pemuliaan jarak pagar di BALITTAS. Di dalam: Mugiono, editor. Simposium dan Pameran Teknologi Isotop dan Radiasi, 2010 Oktober 27-28; Jakarta, Indosesia. Jakarta (ID):
Pusat Aplikasi Teknologi Isotop dan Radiasi (PATIR)- Badan Tenaga Nuklir Nasional (BATAN). Hlm 123-134.

Santoso HB. 1992. Budidaya Sengon. Yogyakarta (ID): Kanisius.

Severiano LC, Lahr FAR, Bardi MAG, Santos AC, Machado LDB. 2010. Influence of gamma radiation on properties of common Brazilian wood species used in artwork. Progress in Nuclear Energy 52(8): 730-734.

Subari D. 2014. Sustainibilitas hutan tanaman industri sengon (Albizia falcataria). Jurnal Riset Industri Hasil Hutan 6(1): 9-14.

Sudarmonowati E, Satria N, Hartati NS, Taryana N, Siregar UJ. 2009. Sengon mutan putative tahan tanah ex-tambang emas. Journal of Applied and Industrial Biotechnology in Tropical Region 2(2): $1-5$.

Suhaya Y, Erningtyas T. 2005. Berat jenis, kadar air, dan penyusutan pada kayu afrika (Maeisopsis eminii). Journal of Wana Mukti Forestry Research 4(1): 50-58.Supranto J. (2004). ANALISIS MULTIVARIAT (Arti dan Interpetasi). Jakarta: Rineka Cipta.

Susila IWW. 2011. Model dugaan volume dan riap tegakan sengon (Paraserianthes falcataria) di Desa Suter, Kintamani Bali. Jurnal Agroteksos. 21(1): 29-38.

Wijayanto N, Nurunnajah. 2012. Intensitas cahaya, suhu, kelembaban dan perakaran lateral mahoni (Swietenia macrophylla King) di RPH Babakan Madang, BPKPH Bogor, KPH Bogor. Jurnal Silvikultur Tropika 3(1): 8-13.

Zanzibar M. 2008. Devigorasi dan invigorasi benih suren (Toona sureni). [Laporan hasil penelitian]. Balai Penelitian Teknologi Perbenihan. Bogor: Badan Penelitian dan Pengembangan Kehutanan.

Zanzibar M, Pujiastuti E, Megawati, Sudrajat D. 2015. Iradiasi sinar gamma $\left({ }^{60} \mathrm{Co}\right)$ untuk meningkatkan perkecambahan dan pertumbuhan bibit tembesu (Fagraea fragrans Roxb.). Jurnal Penenlitian Hutan Tanaman 12(3): 165-174. 